\title{
Preface: conservation of european ponds-current knowledge and future needs
}

\author{
Maria R. Miracle ${ }^{1, *}$, Beat Oertli ${ }^{2}$, Régis Céréghino ${ }^{3} \&$ Andrew Hull ${ }^{4}$ \\ ${ }^{1}$ Dept. Microbiologia i Ecologia. Institut Cavanilles de Biodiversitat i Biologia Evolutiva. University of Valencia. \\ 46100-Burjassot (Valencia). Spain. \\ ${ }^{2}$ hepia Geneva University of Applied Sciences Western Switzerland, CH-1254 Jussy-Geneva, Switzerland. \\ ${ }^{3}$ Université de Toulouse, EcoLab Laboratoire d'Ecologie Fonctionnelle, UMR5245, 118 route de Narbonne, \\ F-31062 Toulouse cedex 9, France. \\ ${ }^{4}$ Liverpool John Moores University. Clarence St. L3 5UG, Liverpool, UK. \\ *Corresponding author: rosa.miracle@uv.es
}

\begin{abstract}
Preface: conservation of european ponds-current knowledge and future needs

Ponds are common elements of the landscape with an important role in the global processes of biosphere and biodiversity preservation. Recent research indicates that ecological characteristics of ponds are different from other inland water systems, but scientific knowledge is still insufficient and poor compared to lakes and rivers. Therefore, whilst indicators and conservation tools have been developed for most aquatic systems, there is also a gap between existing basic information on pond ecology and applied research. The European Pond Conservation Network (EPCN) with the aim of strengthening the links between basic and applied research and pond management organized its $3^{\text {rd }}$ biennial meeting in Valencia (Spain) with the theme "Pond conservation: from science to practice". We present a selection of papers from this conference, which cover the three main topics of the sessions: (1) Management and conservation in practice, (2) Pond ecology at different scales and (3) Temporary ponds. The articles presented develop techniques for assessing the ecological status of this type of ecosystems, evidence the importance of ponds in a global scale, indicate that their conservation must take into account their spatial arrangement in networks, discuss environmental factors that are relevant to biodiversity conservation and provide information on different research areas such as biogeochemical processes, evolution of aquatic biota and community ecology.
\end{abstract}

Key words: Ponds, biodiversity, conservation, temporary ponds, global change.

\section{RESUMEN}

Prefacio: conservación de las charcas europeas-conocimiento actual y necesidades futuras

Las charcas son elementos habituales del paisaje que tienen un importante papel en los procesos globales de la biosfera y en la conservación de la biodiversidad. Investigaciones recientes indican que las características ecológicas de la charcas son diferentes de las de otros sistemas acuáticos, pero los conocimientos científicos de ellas son todavía insuficientes y pobres comparados con los de los lagos y ríos. Por lo tanto, mientras que hay un desarrollo avanzado de herramientas para la conservación de la mayoría de los ecosistemas acuáticos, subsiste un retraso entre los conocimientos básicos de ecología de las charcas y los aspectos aplicados para su correcta gestión. La Red Europea para la conservación de las charcas (EPCN) con el objetivo de estrechar la relación entre el conocimiento fundamental y aplicado y la gestión de las charcas organizó su tercera reunión bienal en Valencia (España) con el lema "Conservación de las charcas: de la ciencia a la práctica". Presentamos aquí una selección de los trabajos expuestos cubriendo los tres tópicos principales de las sesiones: (1) Gestión y conservación en la práctica, (2) ecología de las charcas a diferentes escalas y (3) charcas temporales. Los artículos presentados desarrollan técnicas para la identificación del estado ecológico de este tipo de ecosistemas, ponen de manifiesto la importancia de las charcas en los procesos globales, indican que para su conservación hay que considerar su distribución espacial en redes, discuten los factores ambientales relevantes para la conservación de la biodiversidad y proporcionan información sobre diferentes áreas de investigación como procesos biogeoquímicos, evolución de los organismos acuáticos y ecología de comunidades.

Palabras clave: Charcas, biodiversisidad, conservation, charcas temporales, cambio global. 


\section{INTRODUCTION}

In Europe, ponds are the most widespread aquatic habitat and collectively dominate the total area of continental standing waters. This, that is evident especially in Mediterranean countries where lakes are very scarce, has not been taken into account in local environmental studies and even less in studies of biosphere plumbing. The "emerging role" of ponds is in the title of the first contribution to this issue (Downing 2010), which makes evident, based on recent and improved data, that ponds collectively not only have more surface area than large lakes, but are also more important in storing carbon than large lakes, thus having a significant role in the Earth's carbon balance and climate change. In addition, ponds also play many other valuable roles such as enhancing biodiversity, not only of aquatic organisms but also of terrestrial organisms that depend directly on these ecosystems as well as other indirect beneficial effects such as mitigating diffuse pollution or regulating temperature and humidity. In terms of regional diversity, a network of ponds has been found to make a greater contribution than lakes or rivers (Biggs et al., 2005) and the existence of important interactions between species composition of different pond sites have been appreciated, when large spatial scales are considered (Briers \& Biggs 2005). However, knowledge on ponds is only beginning and since recent studies have evidenced marked differences with lakes, we are aware that knowledge is insufficient and much lower when compared to other aquatic systems. There is a need therefore for further research on the organization and processes not only within ponds, but also among them.

Despite the recent increase in the interest of ponds and awareness of their vulnerability to degradation and fast disappearance of many of them, their protection is still inadequate. For instance, the most substantial piece of water legislation constituted to protect our waters, the European Water Framework Directive, does not apply to water bodies of less than 50 ha, in most Member States, although in some nations, as in Spain, a few smaller lakes have been exceptionally included, due to the fact of the low number of natural water masses with an area greater than the 50 ha. Accordingly, this does not include any additional protection for important ponds. Some ponds, however, are protected under European Community legislation as providing a home for protected habitats listed in Annex I and protected species listed in Annex II and Annex IV of the Habitats Directive 92/43/EEC, mostly to the benefit of Mediterranean ponds. One step forward, however, would be to modify the Directive to recognize ponds or pond areas as an additional water-body type to be protected (EPCN, Pond Manifesto, 2008). Large-scale loss of these habitats, especially in the more arid Southern European countries, will be critical not only for conservation of aquatic and amphibious organisms but also to ameliorate climate change and also to maintain a connected landscape, because ponds, although small, constitute a series of vital stepping stones through the landscape as well as providing many benefits to surrounding ecosystems.

On the other hand, a number of pond conservation initiatives have been undertaken in some countries. In order to strengthen these, coordinate their activities and develop a framework of theoretical and practical knowledge for pond conservation, the European Pond Conservation Network (EPCN), was established at the first European Pond Workshop in 2004. This workshop was held in Geneva (Switzerland), devoted to "Conservation and monitoring of pond Biodiversity" with the objective of synthesizing recent basic and applied knowledge on the topic. One of the main outcomes from this initial meeting was the launching of the EPCN "to promote the awareness, understanding and conservation of ponds in a changing European landscape" (Oertli et al., 2004; 2005a). The EPCN is a European network of people and institutions involved in basic and applied scientific research on pond conservation as well as a range of stakeholders involved directly or indirectly in any aspect of pond conservation. The second European Pond Workshop was devoted to "Conservation of pond biodiversity in changing European landscape" and was held in Toulouse (France) in 2006 where the main objectives were focused on understanding pond ecology, the added value of ponds and pond 
management (Nicolet et al. 2007, Céréghino et al. 2008). The working sessions of this meeting were used to formulate the Pond Manifesto (EPCN, 2008), which had already been drafted at the first European Pond Workshop in 2004. The Manifesto sets out the case for the conservation of ponds, reveals the threats they face and outlines a strategy for their conservation in Europe, based on the knowledge and experience of researchers and practitioners. The Manifesto was delivered at the third EPCN conference in Valencia (Spain) and can be downloaded from the website of the EPCN (www.europeanponds.org).

Since the first workshop the network has been considerably active and has held biennial meetings. This special issue provides a sample of the papers presented at third meeting of the EPCN in Valencia (2008). Another selection of papers from this meeting has been published in a special issue of Hydrobiologia (Oertli et al., 2009) and will also be collected in a volume from the series "Developments in Hydrobiology" (together with papers from the second European Pond workshop published in Hydrobiologia 597, 2008).

\section{THIRD EUROPEAN POND WORKSHOP: SPECIAL ISSUE CONTENT}

The third European Pond workshop called for contributions on Pond conservation: from science to practice, with the aim of bringing together researchers, managers and practitioners to exchange information, concerns and views on common topics under different perspectives to strengthen knowledge on pond ecosystems. It was organized in Valencia under the auspices of EPCN by the Generalitat Valenciana (Conselleria de Medi Ambient) as an action included in the European Union Life-Nature project on "Restoration of priority habitats for amphibians". A total of 123 communications were presented, 38 as oral presentations and 85 as posters (which can be downloaded from http://campus.hesge.ch/epcn/posters_valencia08. asp). The meeting was structured around three topics: (1) Management and conservation in practice, (2) Pond ecology at different scales and
(3) Temporary ponds. In addition, two special working sessions were included in the conference programme. The first session focussed on Pond management success stories and, after the presentation of case studies where successful management had been carried out, was devoted to understanding how we measure "success" and what could be learnt from management failures. It was proposed that the EPCN website could store pond management stories whether successful or not. The second session -Linking pond management to scientific knowledge- was focussed on ways in which better links could be established between scientists and practitioners in order to coordinate fundamental and applied research and develop management practices on a scientific basis. The main issue discussed was ways in which the flow of information between management and research could be improved. This question is important for two reasons. Firstly, practitioners usually do not publish the results of their practices and are therefore not available to the scientific community and, secondly, there is very little applied research on pond management in scientific projects.

The papers selected for this issue cover the three main topics of the meeting. The study of ponds in a global scale is a new and very desirable perspective, which was the theme of the $1^{\text {st }}$ keynote lecture of the meeting. In this lecture Downing (2010), based upon recent developments in data acquisition and mathematical approaches, clearly demonstrates the importance of ponds in global cycles, since they are small but numerous with a disproportionally high intensity of many processes. This review paper updates and illustrates with numbers the global balance of burial and evasion of carbon and the role of ponds in carbon processing. It also opens a great array of suggestions on global limnology and ecology and shows the need to integrate ponds in any study of global processes in the biosphere. Ponds are important beyond their local and regional scale, playing a significant role in global biogeochemical cycles and biodiversity maintenance.

The growing interest in temporary environments was reflected in the $2^{\text {nd }}$ keynote lecture in which Brendonck et al. (2010) started the session 
on temporary ponds with a well documented review of a large series of studies that these authors had undertaken in a series of small ephemeral freshwater rock pools. They indicate how these pools, which usually occur in clusters with different spatial patterns, can be used as model systems to study biological, evolutionary and ecological processes. In addition to the valuable results from their studies together with methodological descriptions, their paper includes attractive conceptual approaches and perspectives on patterns of species dispersal, meta-populations and metacommunities, as well as disturbance and community succession. Recent work, based in part on metapopulation concepts (Hanskii 1999) has evidenced the importance of the interactions, mainly through dispersion, between ponds forming part of networks (Briers \& Biggs 2005). The heterogeneity and gradients of environmental characteristics that display many diminutive idiosyncratic ponds, highly affected by surrounding local factors of their small catchment area, maintain a high regional biodiversity (Jeffries 1998), which may be richer than in other aquatic systems such as rivers, streams or ditches (Williams et al., 2004). Several contribution in past workshops (Cayrou \& Céréghino 2005; Jeffries 2005; De Bie et al., 2008; Oertli et al., 2008) have reinforced the idea that pond networks -pondscapes-, should be considered in any conservation strategy and the spatial and temporal scales should be broadened when developing management proposals. This large scale view is especially significant in temporary ponds (Pretus, 2009). The benefits of the pond landscape view for temporary pond conservation are illustrated in this issue by Diaz-Paniagua et al. (2009) integrating published and new data to describe the high species richness and wide community assembly variation among different ponds and years, dependent on fine gradients of hydrological and/or other factors found in the large numbers of temporary ponds of Doñana National Park (Southern Spain).

The study of temporary waters is far less developed than the study of other aquatic habitats and basic descriptions of these habitats is vital. Temporary ponds are fluctuant environments. Fernandez-Alaez \& Fernandez-Alaez (2010) ex- plore in temporary and permanent ponds, as well, but subject to marked seasonal fluctuations, the drastic changes of main ions and nutrients; firstly, after waterlessness in summer and then after refilling in autumn and spring. Long-standing natural temporary ponds, with a long history of a more or less predictable hydrological pattern, have evolved to start the annual wetting with a highly structured community of relict species not found in any other habitat type. Biodiversity, including active and diapause stages, shapes a stable community that becomes active by relatively predictable environmental pulses and that follows a repetitive process where succession trends can be tracked year after year. This view is well exemplified by the study of seasonal changes, focused mainly on crustaceans, in Sinarcas pond (East Spain) by Sahuquillo \& Miracle (2010). This pond constitutes a true biodiversity hot spot, where communities with a high percentage of endangered relict or rare species are still thriving nowadays (with respect to crustaceans, all groups of large branchiopodes and three coexisting diaptomids). There are not many ponds left with such a high diversity in Europe. The same study indicates that the deepening of a nearby pond has led to impoverishment and disappearance of temporary water specialists. Thus, it is highly recommended that conservation be directed towards maintaining ancient natural ponds as they are, with interventions limited to regulate those activities that could have impacts in its watershed and to remove human activities out of its basin, i.e. out of all the potentially flooding land, albeit it might not replenish to whole capacity all the years. Although this land could go for long dry periods, it should not be considered a waste land neither a land that needs restoration, but an integral part of the pond, in both its aquatic or terrestrial phase, containing a seed and egg bank of both phases.

Ecological assessment and monitoring is a major topic in conservation that has seldom been developed in ponds. As we have noticed above, they are not considered in the European Water Framework Directive by many Member States. However conservation of ponds is a recognized need (Pond Manifesto) due to increasing impacts of environmental alterations as a result, for exam- 
ple, of land use in a changing climate. The papers by Angelibert et al. (2010) and Indermuehle et al. (2010) constitute an advanced step in developing a tool based on a rigorous scientific framework but useful for the "on the ground" practitioners. They propose the IBEM index a simplification of the PLOCH assessment method (Oertli et al., 2005b), which follows the methodology adopted by the European Water Framework Directive, thus the ratio to a reference state is translated into one of five quality classes. To facilitate the method of implementation, a website (http://campus.hesge.ch/ibem) enables the calculation of the index online, and provides support to users on both sampling and assessment methodologies. The IBEM-Index is a rapid assessment standardized method which gives an overall value of pond biodiversity and has proven to be successful in regional screenings or site monitoring in Switzerland as a good indicator of ecological quality. Standardized sampling techniques are one of the key questions to obtain good comparative assessment data, but it is very important to select those that minimize the impact of sampling processes on the ecosystem. In this sense, it is remarkable the contribution of Scher et al. (2010) testing the invertebrate sampling efficiency and representativeness of different and resourceful artificial substrates. In addition to that, the work highlights the importance of the artificial substrate type on its colonization by macroinvertebrates in lentic systems.

Ecological restoration is also one of the management measures; Anton \& Armengol (2010) studied different restored ponds in Albufera Natural Park (Mediterranean Spain coastal area) in relation to zooplankton diversity. One of the conclusions is that the lapsed time since a pond is restored is an important factor for species composition and diversity; but seems to be an important factor mainly in the temporary systems, since the permanent ponds are less influenced.

One of the more drastic restoring measures is directed to the creation of new ponds and several works have indicated the success of this practice (Williams et al., 2008). In this issue, Garmendía \& Pedrola (2010) present a short applied paper addressed to practitioners describing a simple water balance model and its application to a hypothetical wetland pond albeit forced with real meteorological data in an arid country. The model explores how pond depth and shape are important for determining pond hydroperiod. The creation of ponds or modification of natural ones has been an ancient practice to hold water for different uses mainly irrigation and cattle watering. It has been shown that artificial, more or less intensively used ponds, may sustain biodiversity at a regional scale in an agricultural landscape (Céréghino et al., 2008), this being true even in highway stormwater detection ponds (Scher et al., 2004). Wide farm pond landscapes can be found in many agricultural areas of dry countries. In this issue, Leon et al. (2010) based on a comparison of a large number of farm ponds in Andalucia (Southern Spain) with the protected natural wetlands of this region reinforced the same conclusions that farm ponds are important to preserve biodiversity in the agricultural landscape. Species richness and diversity in farm ponds with natural substrates reached similar levels than natural wetlands. However their results show very clearly that ponds constructed or rebuilt with artificial substrates (plastic or concrete) had significantly lower zooplankton species richness than ponds with a natural substrate.

Due to their small size, ponds are very sensitive to the surrounding landscape, and the landscape indicators (Gergel et al., 2002) applied to stream ecology, such as percentage of agricultural land, could also be used to predict a variety of water chemistry parameter in ponds. In the present issue, there is also a contribution that highlights the influence of land uses in the catchment area, in the water chemistry and trophic level of ponds (Kuczyńska-Kippen \& Joniak, 2010). Surrounding land use might as well have an effect on the size of planktonic organisms (Basinska et al., 2010). The last mentioned paper, where the size of the rotifer Filinia is analyzed, shows that size not only varies according to land uses but also in relation to the type of habitat in the pond where they are found: open waters or among emergent or submerged aquatic vegetation. 


\section{PERSPECTIVES}

Interesting new lines of thought have been initiated in pond studies, in the first paper of this issue Downing (2010) argues convincingly that ponds are biogeochemicaly very active and taken collectively a large fraction of carbon sequestration resides in their sediments. However, much work is still needed to quantify carbon and nutrient cycling and storage to understand regional and global budgets of greenhouse gases, at multiple scales of space and time. Ponds are very common landscape elements which originate spatial heterogeneity and are subject to high temporal variability. McClain et al. (2003) defined biogeochemical hot spots and hot moments respectively as patches or episodes that show disproportionately high reaction rates relative to the surrounding matrix or longer intervening time periods and recognized that hot spot and hot moment activity is often enhanced at terrestrial-aquatic interfaces. Therefore pond networks are very important sites with these characteristics and their spatial arrangements must be considered in natural resources management. Over a quarter of a century ago, Likens (1984) indicated the importance to protect beyond the shore line, because inland waters are interconnected elements of the landscape (surface and subterranean waters, airshed, soils, aquatic and terrestrial organisms). Land use changes affect the hydrologic routing and associated processing of transported materials which may alter natural linkages and perturb pond ecology, thus conservation measures must use watershed-ecosystem approaches.

Hydrological variation and spatial arrangement of ponds is very important for aquatic and terrestrial biota as well; moreover spatial heterogeneity and pond connectivity may increase substantially species richness in a metacommunity structure. Also individual sites, despite their small size, have been recognized to be truly biodiversity hot spots. These ponds, probably remnants of past larger network systems, should be preserved as they are and conservation measures will have to be taken in the watershed if they are threatened by intensifying agriculture or other land uses. Since we know that processes are logarithmic and hysteresis occurs in the response of aquatic ecosystems to external forcing (Sheffer, 1998) in many sites it may be urgent to prevent further irreversible alterations. In the case of eutrophication, a sudden shift may occur after long lasting pollution; when a threshold is exceeded the system is transmuted to an alternative state and it will not respond to decreased pollution loads, until loads are reduced considerably below the mentioned threshold. But then, the system response to cessation of pollution will not retrace the same trajectory to initial conditions and if losses of biodiversity occur associated to the point of injuring the seed and egg bank, it will never return to its original state. It is preferable to preserve natural sites than to have to recover degraded ecosystems later. Most ponds or pond areas have small catchment areas that facilitate the identification of impacts, so conservation approaches including catchment area could be easily incorporated. Recent projects, such as the identification of Important Areas for Ponds (IAP project), already started successfully in the UK (www. pondconservation.org.uk/pond_hap/iap.htm) will fulfil the lack of information on these environments and encourage better protection at large scales of biodiversity and pond resources. Many ponds have been created or modified for farm use. There is now a challenge to think ecologically in the future construction or management of small artificial water bodies. In agreement to recent results, to preserve biodiversity, constructed ponds have to mimic natural systems. Among the more important factors to consider are the maintenance of natural substrates (Boavida 1999), hydrology, morphology and reduction of the contamination of inflowing waters.

In 2010, 'The Year of Biodiversity', the 4th EPCN Conference will be held in Berlin (Erkner), with the theme "Eyes of the Landscape-value of ponds in the $21^{\text {st }}$ century". Its objective is to intensify exchange of experiences of pond experts from both, basic sciences and applied work on conservation and management to address the issues of the Pond Manifesto (2008), as the organizers indicated in their invitation to the Conference. 


\section{ACKNOWLEDGEMENTS}

We are very grateful to the organizers of the EPCN meeting in Valencia, especially to Ignacio Lacomba, Vicente Sancho and Benjamí Perez for the excellent organization of a very valuable meeting. We acknowledge the support of the Life-Nature project "Restoration of priority habitats for amphibians" (LIFE05/NAT/E/00060) and of the "Conselleria de Medi Ambient, Aigua, Urbanisme i Habitatge of the Generalitat Valenciana". Thanks also to all the manuscript reviewers and to Joan Armengol (chief editor of Limnetica) and the "Asociación Iberica de Limnologia" (AIL) for the publication of this special issue.

\section{REFERENCES}

ANGÉLIBERT, S., V. ROSSET, N. INDERMUEHLE \& B. OERTLI. 2010. The pond biodiversity index "IBEM": a new tool for the rapid assessment of biodiversity in ponds from Switzerland. Part I. Index development. Limnetica, 29: 93-104.

ANTÓN-PARDO, M. \& X. ARMENGOL. 2010. Zooplankton community from restored peridunal ponds in L'Albufera Natural Park. Limnetica, 29: 133-144.

BASIŃSKA A., N. KUCZYŃSKA-KIPPEN, K. ŚWIDNICKI. 2010. The body size distribution of Filinia longiseta (Ehrenberg) in different types of small water bodies in the Wielkoposka región. Limnetica, 29: 171-182.

BIGGS, J., P. WILLIAMS, P. WHITFIELD, P. NICOLET \& A. WEATHERBY. 2005. 15 years of pond assessment in Britain: results and lessons learned from the work of Pond Conservation. Aquatic Conserv.: Mar. Freshw. Ecosyst., 15: 693-714.

BOAVIDA, M. J. 1999. Wetlands: most relevant structural and functional aspects. Limnetica, 17: 57-63.

BRENDONCK, L., M. JOCQUE, A. HULSMANS \& B. VANSCHOENWINKEL. 2010. Pools 'on the rocks': freshwater rock pools as model system in ecological and evolutionary research. Limnetica, 29: 25-40.

BRIERS, R. A. \& J. BIGGS. 2005. Spatial patterns in pond invertebrate communities. Separating environments and distance effects. Aquatic Conserv: Mar. Freshw. Ecosyst., 15: 549-557.
CAYROU, J. \& R. CÉRÉGHINO. 2005. Life-cycle phenology of some aquatic insects: implications for pond conservation. Aquatic Conserv: Mar. Freshw. Ecosyst., 15: 559-571.

CÉRÉGHINO, R., A. RUGGIERO, P. MARTY, S. ANGÉLIBERT, 2008. Biodiversity and distribution patterns of freshwater invertebrates in farm ponds of a south-western French agricultural landscape. Hydrobiologia, 597: 43-51.

CÉRÉGHINO, R., J. BIGGS, B. OERTLI \& S. DECLERCK. 2008. The ecology of European ponds: defining the characteristics of a neglected freshwater habitat. Hydrobiologia, 597: 1-6.

DE BIE, T., S. DECLERCK, K. MARTENS, L. DE MEESTER \& L. BRENDONCK, 2008. A comparative analysis of cladoceran communities from different water body types: patterns in community composition and diversity. Hydrobiologia, 597: 19-27.

DÍAZ-PANIAGUA, C., R. FERNÁNDEZ-ZAMUDIO, M. FLORENCIO, P. GARCÍA-MURILLO, C. GÓMEZ-RODRÍGUEZ, A. PORTHEAULT, L. SERRANO \& P. SILJESTRÖM. 2010. Temporary ponds from Doñana National Park: A system of natural habitats for the preservation of aquatic flora and fauna. Limnetica, 29: 41-58.

DOWNING, J. 2010. Emerging global role of small lakes and ponds. Little things mean a lot. Limnetica, 29: 9-24.

EPCN 2008, Pond Manifesto, www.europeanponds. org

FERNÁNDEZ-ALAEZ, C. \& M. FERNÁNDEZALAEZ. (2010) Temporary ponds of Eastern Spain: Limnological typology and human impact. Limnetica, 29: 59-74.

GARMENDIA, A. \& J. PEDROLA-MONFORT. 2010. Simulation model comparing the hydroperiod of temporary ponds with different shapes. Limnetica, 29: 145-152.

GERGEL, SE., TURNER, M. G., MILLER J. R., STANLEY, E. H., MELACK, J. M. 2002. Landscape indicators of human impacts to riverine systems. Aquatic Sci., 64: 118-128.

HANSKI, I. 1999. Metapopulation Ecology. Oxford University Press. Oxford, UK. 313 pp.

INDERMUEHLE, N., S. ANGÉLIBERT, V. ROSSET \& B. OERTLI. 2010. The pond biodiversity index "IBEM": a new tool for the rapid assessment of biodiversity in ponds from Switzerland. Part 2. Method description and examples of application. Limnetica, 29: 105-120. 
JEFFRIES, M. 1998. Pond macrophyte assemblages, biodisparity and spatial distribution of ponds in the Northumberland coastal plain, UK. Aquatic Conserv.: Mar. Freshw. Ecosyst., 8: 657-667.

JEFFRIES, M. 2005b.Small ponds and big landscapes: the challenge of invertebrate spatial and temporal dynamics for European pond conservation. Aquatic Conserv.: Mar. Freshw. Ecosyst., 15: 541-547.

KUCZYŃSKA-KIPPEN, N. \& T. JONIAK. 2010. Chlorophyll $a$ and physical-chemical features of small water bodies as indicators of land use in the Wielkopolska region (Western Poland). Limnetica, 29: 163-170.

LEÓN, D., P. PEÑALVER, J. CASAS, M. JUAN, F. FUENTES, I. GALLEGO \& J. TOJA. 2010. Zooplankton richness in farm ponds of Andalusia (Southern Spain). A comparison with natural wetlands. Limnetica, 29: 153-162.

LIKENS, G. 1984. Beyond the shore line: a watershed-ecosystem approach. Verh. Internat. Verein. Limnol., 22: 1-22.

McCLAIN, M. E., E. W. BOYER, C. L. DENT, S. E. GERGEL, N. B. GRIMM, P. M. GROFFMAN, S. C. HART, J. W. HARVEY, C. A. JOHNSTON, E. MAYORGA, W. H. McDOWELL \& G. PINAY. 2003. Biogeochemical Hot Spots and Hot Moments at the Interface of Terrestrial and Aquatic Ecosystems. Ecosystems, 6: 301-312.

NICOLET P., A. RUGGIERO \& J. BIGGS. 2007. Second European Pond Workshop: Conservation of pond biodiversity in a changing European landscape. Ann. Limnol.-Int. J. Lim., 43: 77-80.

OERTLI, B., D. AUDERSET JOYE, N. INDERMUEHLE, R. JUGE \& J.-B. LACHAVANNE. 2004. 1st European Pond Workshop "Conservation and monitoring of pond biodiversity" Arch. Sci., 57: 69-72.

OERTLI, B., J. BIGGS, R. CÉRÉGHINO, P. GRILLAS, P. JOLY, \& J.-B. LACHAVANNE. 2005 (a). Conservation and monitoring of pond biodiversity. Aquatic Conserv: Mar. Freshw. Ecosyst., 15: 535540.
OERTLI, B., D. AUDERSET JOYE, E. CASTELLA, R. JUGE, A. LEHMANN \& J.-B. LACHAVANNE. 2005 (b). PLOCH: a standardized method for sampling and assessing the biodiversity in ponds. Aquatic Conserv.: Mar. Freshw. Ecosyst., 15: 665-679.

OERTLI, B., N. INDERMUEHLE, S. ANGÉLIBERT, H., HINDEN \& A. STOLL. 2008. Macroinvertebrate assemblages in 25 high alpine ponds of the Swiss National Park (Cirque of Macun) and relation to environmental variables. Hydrobiologia, 597: 29-41.

OERTLI, B., R. CÉRÉGHINO, A. HULL \& M. R. MIRACLE. 2009. Pond conservation: from science to practice. Hydrobiologia, 634: 1-9.

PRETUS, J. LL. 2009. Mediterranean temporary ponds: life histories for unwarranted offbeat environments. In: International Conference on Mediterranean Temporary Ponds. Proceedings \& Abstracts. P. Fraga-Arguimbau (ed.). Reserca, 14: 2335. Consell Insular de Menorca. Maó.

SAHUQUILLO, M. \& M. R. MIRACLE. 2010. Crustacean and rotifer seasonality in a Mediterranean temporary pond with high biodiversity (Lavajo de Abajo de Sinarcas, Eastern Spain). Limnetica, 29: 75-92.

SCHER, O., P. CHAVAREN, M. DESPRAUX \& A. THIÉRY, 2004. Highway stormwater detention ponds as biodiversity islands? Archive des Sciences, 57: 121-130.

SCHER, O., K. E. MCNUTT \& A. THIÈRY. 2010. Designing a standardised sampling method for invertebrate monitoring: a pilot experiment in a motorway retention pond. Limnetica, 29: 121-132.

WILLIAMS, P., M. WHITFIELD, J. BIGGS, S. BRAY, G. FOX, P. NICOLET \& D. SEAR, 2004. Comparative biodiversity of rivers, streams, ditches and ponds in an agricultural landscape in Southern England. Biological Conservation, 115: 329-341.

WILLIAMS, P., M. WHITFIELD \& J. BIGGS, 2008. How can make new ponds biodiverse? A case study monitored over 7 years. Hydrobiologia, 597: 137-148. 